\title{
Cobalt(II) complexes with 1,10-phenanthroline alone and mixed with cytoside: Synthesis and antibacterial activities
}

\author{
Atakilt Abebe ${ }^{1 *}$, Girma Bayissa ${ }^{1}$, Abreham Sendek $^{1}$, Mulugeta Kibret ${ }^{2}$ \\ ${ }^{1}$ Department of Chemistry, Science College, Bahir Dar University \\ ${ }^{2}$ Department of Biology, Science College, Bahir Dar University
}

\begin{abstract}
Cobalt can bind to a range of biomolecules forming complexes that are suitable for use in various biological applications. Different ligands could be used to tune the properties of cobalt compounds whose ligand exchange rates become close to those of cellular processes. In this study, two complexes were synthesized from 1,10-phenanthroline alone as $\left[\mathrm{Co}(\text { phen })_{2}\left(\mathrm{H}_{2} \mathrm{O}\right)_{2}\right] \mathrm{Cl}_{2}$ and from both 1,10-phenanthroline and cytoside as $\left[\mathrm{Co}(\mathrm{phen})_{2}(\mathrm{Cyt}) \mathrm{H}_{2} \mathrm{O}\right] \mathrm{Cl}$. The synthesis was checked using halide test, conductance measurement as well as spectroscopic (AAS, FTIR, Uv-vis) analysis. In vitro antibacterial activities of the two metal complexes were tested against Staphylococcus aureus, methicilin resistant staphylococcus aureus (MRSA), Streptococcus pneumoniae, Escherichia coli, Klebsiella pneumoniae and Shegella boydii. These complexes showed better activities than the commercially available control drugs (chloramphenicol and ciprofloxacin) against certain strains of bacteria. Better inhibition zones were exhibited by $\left[\mathrm{Co}(\mathrm{phen}){ }_{2}(\mathrm{Cyt})\left(\mathrm{H}_{2} \mathrm{O}\right)\right] \mathrm{Cl}$ on MRSA $(4.8 \%)$ and $E$. coli $(21.4 \%)$ than chloramphenicol. Likewise, $11.9 \%$ and $22.8 \%$ more zones of inhibition than ciprofloxacin were shown against MRSA and E. coli, respectively. On the other hand, $\left[\mathrm{Co}(\mathrm{Phen})_{2}\left(\mathrm{H}_{2} \mathrm{O}\right)_{2}\right] \mathrm{Cl}$ showed $5.3 \%$ and $3.0 \%$ more zones of inhibition against $S$. aurous and $S$. boydii, respectively, better than ciprofloxacin.
\end{abstract}

Keywords/phrases: Mixed ligand complex, 1,10-phenanthroline, Cytosine, Cytoside, Antimicrobial activity DOI: http://dx.doi.org/10.4314/ejst.v11i2.1

\section{INTRODUCTION}

The rapid increase in the number of multidrugresistant bacteria is becoming a global concern making the discovery of novel active compounds a matter of urgency (Henderson 2006). Originating many of the crude drugs used for medicinal preparations from wild growing plants and animals is threatening the ecology of the globe (Cordell, 2011). Transition metal complexes have several features that are made use of in many areas of modern medicine (Orvig and Abrams 1999). For instance, pharmaceutical industries have considered them as alternatives to conventional drugs which originate from wild sources. This is because the properties of the transition metals can be tuned by coordinating with different ligands (Wilkins, 1974; Lawrence, 2010; Sears et al., 2010). These include stabilization of different oxidation states and modulation of the solvophilicity, electrophilic and nucleophilic properties of the metal ion (Tolman, 1977; Boyer

\footnotetext{
*Corresponding author: atakiltabebe1@gmail.com

(C) This is an Open Access article distributed under the terms of the Creative Commons Attribution License (http://creativecommons.org/licenses/CC BY4.0).
} 
et al., 2010; Goo et al., 2015). In coordination, it is not only the properties of metal ions that are modified but also are the properties of the ligands themselves (Atakilt Abebe and Tizazu Hailemariam, 2016). The pharmacological activities and their crucial role in DNA/RNA base pairing through several hydrogen-bonding patterns of free oxypyrimidines such as cytosine can significantly change after complex formation (Patel et al., 2012; Mohapatra and Verma, 2013). The medicinal activities (Mesmaeker et al., 1996; Turel 2002; Leung et al., 2015) of transition metal complexes occur due to their penetration into the lipid membrane which enables them to disrupt the normal activities of the bacteria (Lakshmi et al., 2009) and their potential to bind DNA via a multitude of interactions and to cleave the duplex by virtue of their intrinsic chemical, electrochemical and photochemical activities (Singh et al., 1983; Barton et al., 1986; Barton, 1990; Long and Barton, 1990; Turro et al., 1991; Murphy and Barton, 1992; Sigel and Sigel, 1996; Arounaguiri and Maiya, 1999). Prominent among the various metal complexes employed so far are those complexes which incorporate 1,10-phenanthroline (phen) as a ligand (Atakilt Abebe et al, 2017; Turel et al., 2015). One advantage in the use of these metallo-intercalators for such studies is that the ligands or the metal ion in them can be varied in an easily controlled manner to facilitate individual applications (Richards and Rodger, 2007; Terron et al., 2007). In this regard, numerous investigations on the properties and applications of cobalt complexes were made (Kong and Xie, 2000; Boerner and Zaleski, 2005; Jiao et al., 2005; Zeglis et al., 2007; Keene et al., 2009). Nevertheless, there is no report on the chemistry of $\mathrm{Co}(\mathrm{II})$ complex containing 1,10-phenanthroline alone as $\left[\mathrm{Co}(\text { phen })_{2}\left(\mathrm{H}_{2} \mathrm{O}\right)_{2}\right] \mathrm{Cl}_{2}$ and/or mixed with cytoside as $\left[\mathrm{Co}(\text { phen })_{2}(\mathrm{Cyt})\left(\mathrm{H}_{2} \mathrm{O}\right)\right] \mathrm{Cl}$ (Hiort et al.. 1993; Dow et al., 1996; Cheng et al., 1999; Guest et al., 2004; Chen et al., 2010; Zhang et al., 2010).

The conveniently placed nitrogen atom along with its rigid planar structure, hydrophobic, electronpoor heteroaromatic and $\pi$-acidic properties cooperatively make 1,10-phenanthroline a classic chelating bidentate ligand. These properties enable it to have stacking interaction ability with DNA base pairs (Pyle et al., 1989; Schaeffer et al., 1996; Coury et al., 1997; Lincoln and Norden, 1998).

Cytosine is a chemically inert oxypyrimidine heteroaromatic molecule. Its inertness is changed by complex formation. Its activity is favored in its cytoside $\left(\mathrm{Cyt}^{-}\right)$form which is derived by deprotonation of cytosine. It plays a crucial role in DNA/RNA base pairing through several hydrogenbonding patterns (Portalone, 2011; Verma et al., 2012). The ring nitrogen with the acidic hydrogen is the binding site.

The purpose of this study is to examine the effects of 1,10-phenanthroline alone and mixed with cytoside on the biological activity of Co(II). The complex would orchestrate the inherent properties of its components. This includes the binding ability of cobalt with a range of biomolecules, the unique stacking interaction ability of 1,10-phenanthroline on cell genetic material, the interaction of cytoside through hydrogen bonding with guanine residue of the genetic material. The latter phenomena ultimately results strong antimicrobial activity of the complexes. 


\section{EXPERIMENTAL}

\section{Chemicals}

All chemicals used in this work are : 1,10-Phenanthroline monohydrate (BDH chemical Ltd., Poole, England), cytosine (ACROS), Mueller-Hinton agar powder (Oxoid, England), $\mathrm{KBr}, \mathrm{CoCl}_{2} \cdot 6 \mathrm{H}_{2} \mathrm{O}, \mathrm{NaCl}, \mathrm{AgNO}_{3}, \mathrm{NaOH}$, concentrated $\mathrm{H}_{2} \mathrm{SO}_{4}$, concentrated $\mathrm{HNO}_{3}(69-27$ $\%$ ), and $\mathrm{BaCl}_{2} \cdot 2 \mathrm{H}_{2} \mathrm{O}$ (all Blulux Laboratories Ltd., India).

\section{Instruments and methods}

The electronic conductance were measured using $10^{-3} \mathrm{M}$ solution of each complex in deionized water with JENWAY 4200 conductivity meter at room temperature. The electronic spectra were recorded in the 200-800 $\mathrm{nm}$ region on Sanyo SP65 UV/VIS spectrophotometer. IR spectra were recorded using $\mathrm{KBr}$ discs in the 4000-400 $\mathrm{cm}^{-1}$ region on AVATAR 330 FT-IR Thermo Nicolet spectrophotometer. Cobalt content was determined by Analytik Jena nov AA300 model atomic absorption spectrophotometer digesting $5.75 \mathrm{mg}$ of each complex in concentrated nitric acid and diluting using distilled water. Melting points were determined using STONE, STAFFORDSHIRE, ST15 OSA, UK digital melting point apparatus. Chloride ions were determined thermogravimetrically using the $\mathrm{AgCl}$ precipitate obtained from the mixture of $10 \mathrm{~mL}$ solution of $8 \mathrm{mg}$ of each complex in distilled water with excess $\mathrm{AgNO}_{3}$ solution. The different bacterial isolates were collected from the University of Gondar, College of Medicine and Health Sciences Hospital. The antibacterial activities were tested at Microbiology Laboratory of Biology Department, Bahir Dar University.

\section{Synthesis}

\section{Synthesis of $\left[\mathrm{Co}(\text { phen })_{2}\left(\mathrm{H}_{2} \mathrm{O}\right)_{2}\right] \mathrm{Cl}_{2}$}

A methanolic solution of 1,10-phenanthroline monohydrate $(0.80 \mathrm{~g}, 4.0 \mathrm{mmol})$ was added from a dropping funel to a methanolic solution of $\mathrm{CoCl}_{2} \cdot 6 \mathrm{H}_{2} \mathrm{O}(0.461 \mathrm{~g}, 2.0 \mathrm{mmol})$ while stirring magnetically in an ice bath for about three hours. The stirring continued for additional three hours after the final drop of the solution containing the ligand when the thin layer chtomatography (TLC) follow up indicated the completion of the reaction. A pinkish homogeneous solution was obtained. The solvent was removed in vacuum. Brown powder was collected and washed three times with acetone to remove any unreacted 1,10-phenanthroline (Atakilt Abebe and Tizazu Hailemariam, 2016).

\section{Synthesis of [Co(Phen $\left.)_{2}(\mathrm{Cyt})\left(\mathrm{H}_{2} \mathrm{O}\right)\right] \mathrm{Cl}$}

An aqueous solution of sodium cytoside obtained from a reaction between cytosine $(0.126 \mathrm{gm}, 1.0$ $\mathrm{mmol}$ ) and sodium hydroxide (0.046 gm, $1.0 \mathrm{mmol})$ was added from a dropping funnel to an aqueous solution of $\left[\mathrm{Co}(\mathrm{Phen})_{2}\left(\mathrm{H}_{2} \mathrm{O}\right)_{2}\right] \mathrm{Cl}_{2}(0.724 \mathrm{gm}, 1$ mmol) while stirring at room temperature. The mixture was allowed to stir for three hours when the TLC follow up indicated the completion of the reaction. The resulting reaction product mixture was mixed with $50 \mathrm{ml}$ dichloromethane and stirred for 15 minutes and allowed to stand overnight. The organic (dichloromethane) phase in which the intended complex product is soluble was separated using separatory funnel. The dichloromethane was removed using rotary evaporator and a dark brown powder was collected (Atakilt Abebe and Tizazu Hailemariam, 2016). The product was recrystallized from methanol. The synthetic strategy is indicated in Scheme 1. 


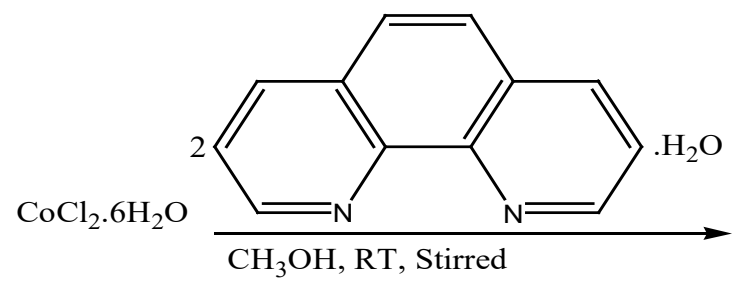

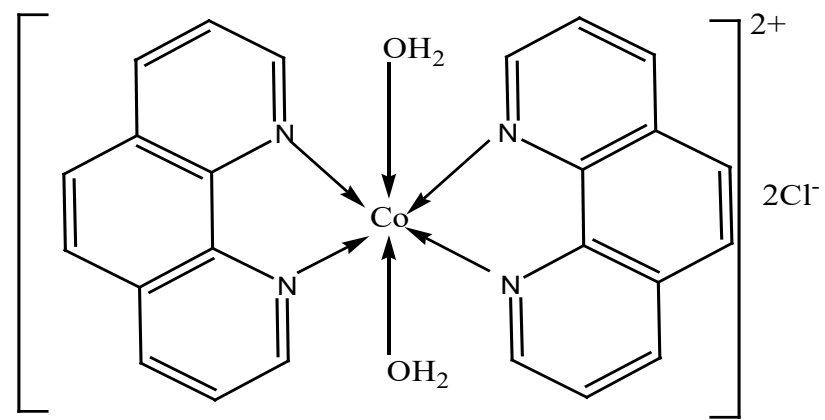<smiles>COC(O)(O)O</smiles>

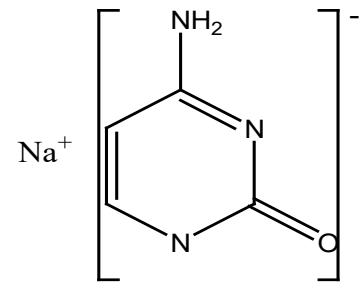

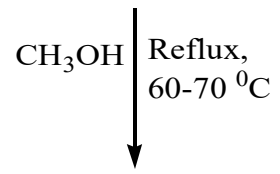

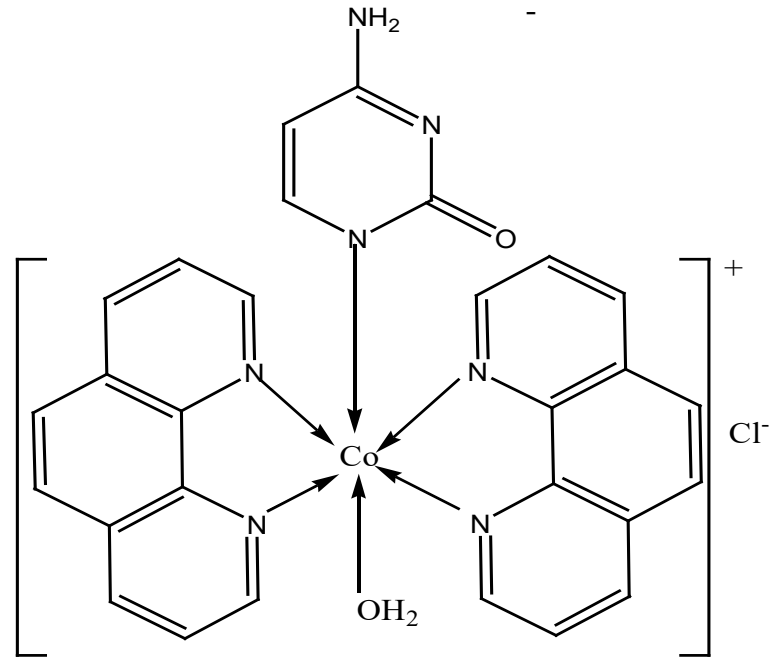

Scheme 1: Synthesis path of the complex

\section{Antimicrobial activity testing}

The in vitro antibacterial activity of the salt, ligands and complexes were tested against three Gram-positive bacteria: Staphylococcus aureus, Methicillin resistant Staphylococcus aureus (MRSA), Streptococcus pneumoniae and three strains of Gram-negative bacteria: Escherichia coli, Klebsiella pneumonia and Shigella boydii by the cork borer method using nutrient agar as

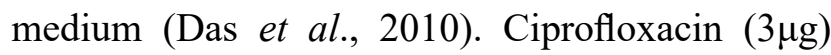
and chloramphenicol $(30 \mu \mathrm{g})$ were used as standard drugs.

A stock solution $\left(10^{-2} \mathrm{~mol} \mathrm{~L}^{-1}\right)$ of $\left[\mathrm{Co}(\mathrm{phen})_{2}(\mathrm{Cyt})\right.$ $\left.\left(\mathrm{H}_{2} \mathrm{O}\right)\right] \mathrm{Cl}$ in water was prepared and serially diluted in order to find the minimum inhibitory 
concentration (MIC) value (Ncube et al., 2008). Test extract loaded discs inoculated with microorganisms were incubated at $37{ }^{\circ} \mathrm{C}$ for $24 \mathrm{~h}$. During the incubation period, the test solution diffused and the growth of the inoculated microorganisms was affected.

\section{RESULTS AND DISCUSSION}

The appearance, melting point, elemental estimation, yield and molar conductivity data of the complex are shown in Table 1.

Table 1: Physical and analytical data of the complexes is attributed to the decrease in its ionicity as well as the decrease in the speed of the mobility of the cation due to the coordination of cytoside which increased its molar mass as well as the possible increase in hydrogen bonding of the primary amine on the cytoside with the solvent water molecules (Atkins 1994).

\section{Electronic spectra}

The electronic spectra of the ligands and complexes are displayed in Table 2 and Figure 1. The coordination of the ligands to the metal ion is evident from the change in the transition

\begin{tabular}{|c|c|c|c|c|c|}
\hline \multirow{2}{*}{$\begin{array}{c}\text { Complex } \\
\text { (color) }\end{array}$} & \multirow{2}{*}{$\begin{array}{l}\text { Melting } \\
\text { point/ }{ }^{0} \mathrm{C}\end{array}$} & \multirow{2}{*}{$\begin{array}{l}\text { Yield, } \\
(\%)\end{array}$} & \multicolumn{2}{|c|}{$\begin{array}{c}\text { Elemental estimation } \\
\text { Calculated (found) ( \%) }\end{array}$} & \multirow[t]{2}{*}{$\begin{array}{l}\Lambda_{\mathrm{M}}\left(\mathrm{S} \mathrm{cm}^{2} \mathrm{~mol}^{-}\right. \\
\end{array}$} \\
\hline & & & Co & $\mathrm{Cl}$ & \\
\hline$\left[\mathrm{Co}(\text { phen })_{2}\left(\mathrm{H}_{2} \mathrm{O}\right)_{2}\right] \mathrm{Cl}_{2}$ (Yellow) & $325-327$ & 73.5 & $11.21(10.98)$ & $13.49(13.25)$ & 138.46 \\
\hline $\begin{array}{l}{\left[\mathrm{Co}(\text { phen })_{2}(\mathrm{Cyt})\left(\mathrm{H}_{2} \mathrm{O}\right)\right] \mathrm{Cl}(\text { Dark }} \\
\text { brown })\end{array}$ & $177-179$ & 75.37 & $10.13(9.95)$ & $6.09(5.92)$ & 83.23 \\
\hline
\end{tabular}

\section{Molar conductance of the metal complexes}

The conductance measurements recorded for $10^{-3} \mathrm{M}$ solutions of the metal complexes in water are indicated in Table 1. $\left[\mathrm{Co}(\text { phen })_{2}\left(\mathrm{H}_{2} \mathrm{O}\right)_{2}\right] \mathrm{Cl}_{2}$ and $\left[\mathrm{Co}(\text { phen })_{2}(\mathrm{Cyt})\left(\mathrm{H}_{2} \mathrm{O}\right)\right] \mathrm{Cl}$ are 1: 2 and 1:1 type electrolytes, respectively (Bard et al. 1980), which supports the chloride estimation experiment result. The decreased conductivity of $\left[\mathrm{Co}(\mathrm{phen})_{2}(\mathrm{Cyt})\right.$ $\left.\left(\mathrm{H}_{2} \mathrm{O}\right)\right] \mathrm{Cl}$ compared with $\left[\mathrm{Co}(\text { phen })_{2}\left(\mathrm{H}_{2} \mathrm{O}\right)_{2}\right] \mathrm{Cl}_{2}$ absorptions. The complexes exhibited simple characteristic $d-d$ transitions. The difference in the band position for $\mathrm{d}-\mathrm{d}$ transition absorption of $\mathrm{CoCl}_{2} \cdot 6 \mathrm{H}_{2} \mathrm{O}$ and the complexes may be explained by assuming different electronic environment around the metal ion following the coordination. The maximum absorption wave length of the complexes shows significant difference from that of $\mathrm{CoCl}_{2} \cdot 6 \mathrm{H}_{2} \mathrm{O}$ and shifts to lower frequencies indicating different splitting pattern of the d-orbitals (Table 2). 


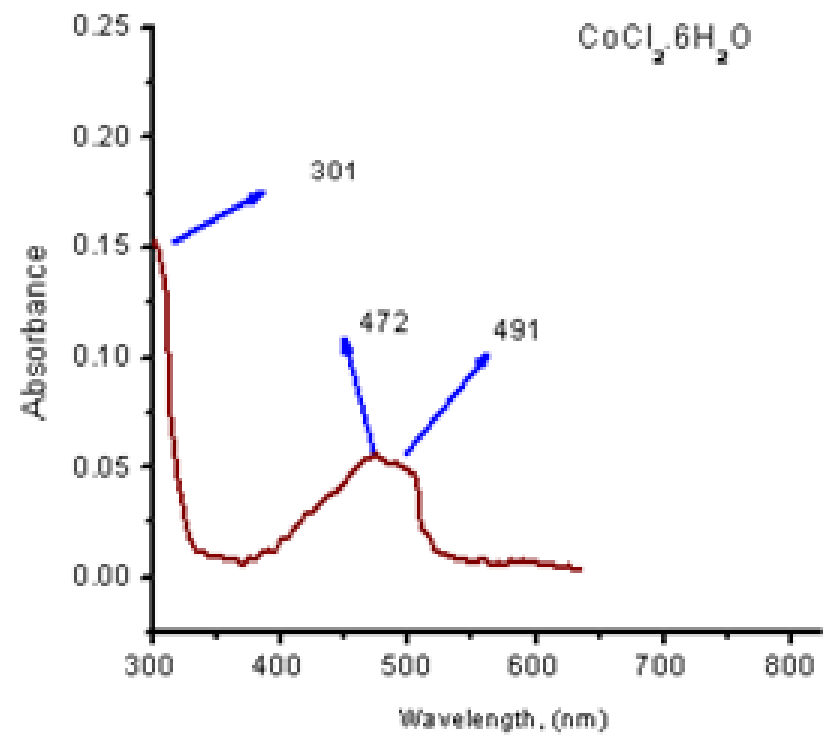

(a)

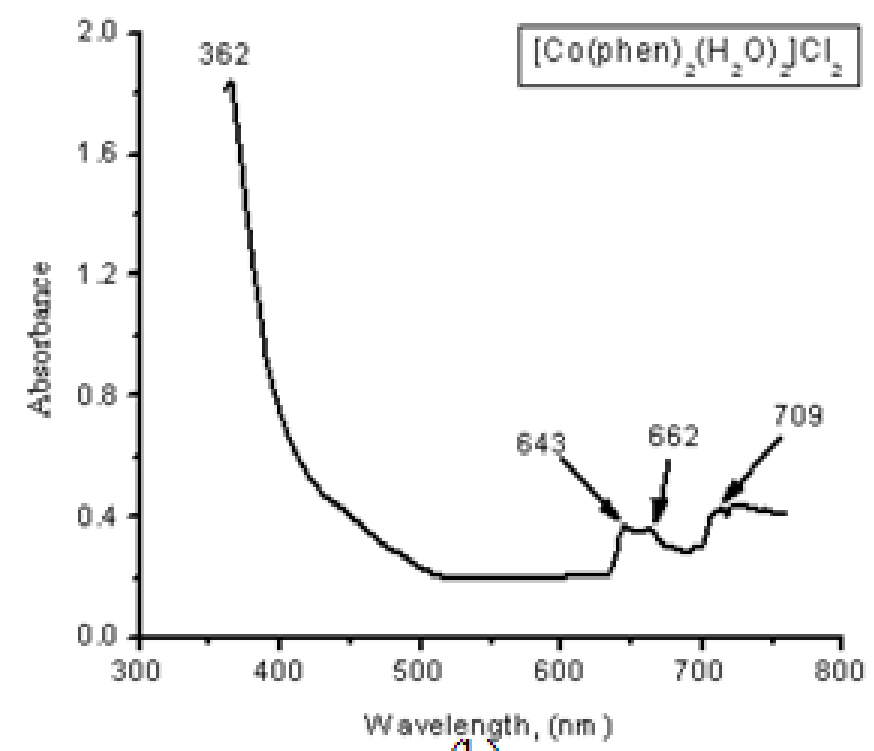

(b)

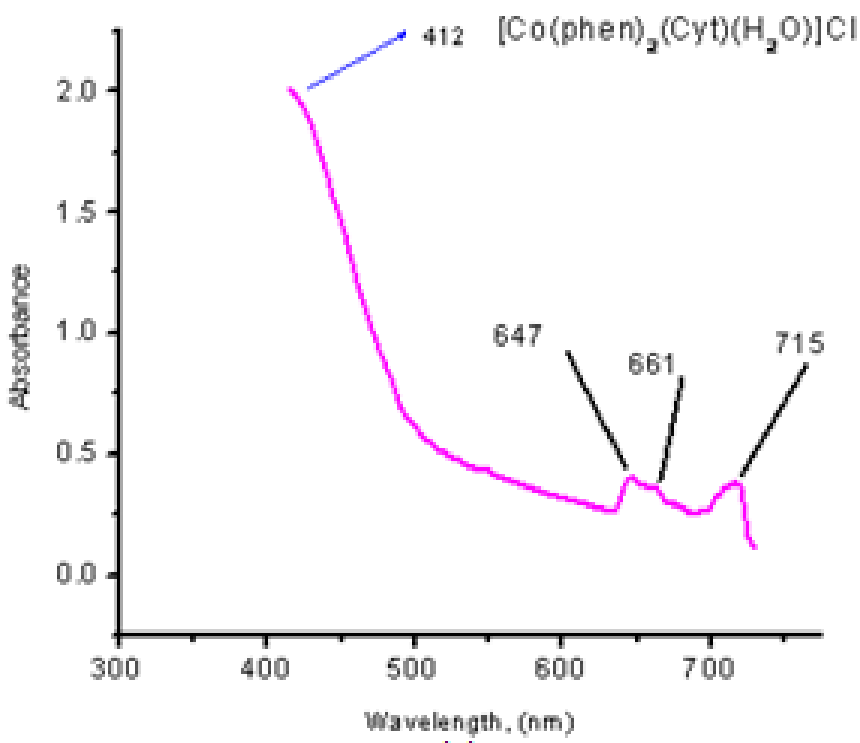

(c)

Figure 1: Electronic spectra of (a) $\mathrm{CoCl}_{2} \cdot 6 \mathrm{H}_{2} \mathrm{O}$, (b) $\left[\mathrm{Co}(\text { phen })_{2}\left(\mathrm{H}_{2} \mathrm{O}\right)_{2}\right] \mathrm{Cl}_{2}$ and (c) $\left[\mathrm{Co}(\text { phen })_{2}(\mathrm{Cyt})\left(\mathrm{H}_{2} \mathrm{O}\right)\right] \mathrm{Cl}$

As 1,10-phenanthroline is a very strong field chelating ligand, it forms shorter and stronger bonds than the weak field $\mathrm{H}_{2} \mathrm{O}$. This results in splitting patterns of the energy states ${ }^{4} \mathrm{~T}_{2 \mathrm{~g}}$ and ${ }^{4} \mathrm{~T}_{\mathrm{gg}}(\mathrm{F})$, which equate with a $\mathrm{t}_{2 \mathrm{~g}}{ }^{5} \mathrm{e}_{\mathrm{g}}^{2}$ configuration (Housecroft and Sharpe, 2005; Missler and Tarr, 2004). The splitting of ${ }^{4} \mathrm{~T}_{2 \mathrm{~g}}\left(\mathrm{t}_{2 \mathrm{~g}} \mathrm{e}_{\mathrm{g}}{ }^{2}\right.$ to $\mathrm{t}_{2 \mathrm{~g}}{ }^{5}$ and $\left.\mathrm{e}_{\mathrm{g}}^{2}\right)$ is significant in $\left[\mathrm{Co}(\mathrm{Phen})_{2}\left(\mathrm{H}_{2} \mathrm{O}\right)_{2}\right] \mathrm{Cl}_{2}$; consequently, the energy gap of ${ }^{4} \mathrm{~T}_{2 \mathrm{~g}}\left(\mathrm{e}_{\mathrm{g}}\right)$ orbital from ${ }^{4} \mathrm{~T}_{1 \mathrm{~g}}(\mathrm{~F})$ is minimized and the absorption wave length increases. Similarly, when the water molecule is replaced by a stronger field cytoside to form $\left[\mathrm{Co}(\mathrm{Phen})_{2}(\mathrm{Cyt})\left(\mathrm{H}_{2} \mathrm{O}\right)\right] \mathrm{Cl}$, the energy gap between $\mathrm{t}_{2 \mathrm{~g}}{ }^{5}$ and $\mathrm{e}_{\mathrm{g}}{ }^{2}$ of $\left({ }^{4} \mathrm{~T}_{2 \mathrm{~g}}\right)$ increases while the gap between ${ }^{4} \mathrm{~T}_{1 \mathrm{~g}}(\mathrm{~F})$ and ${ }^{4} \mathrm{~T}_{2 \mathrm{~g}}$ states decreases such that a lower energy is absorbed for the transition. Distorted octahedral geometry is proposed to the complex. Table 2 gives a summary of the electronic transitions of the ligands, the salt and the synthesized complexes. 
Table 2: The maximum absorption wave length and the corresponding transitions of the salt and complexes

\begin{tabular}{lll}
\hline Compounds & Absorption bands/nm & Transitions \\
\hline $\mathrm{CoCl}_{2} \cdot 6 \mathrm{H}_{2} \mathrm{O}$ & 301 & $\mathrm{LMCT}$ \\
& 472 & ${ }^{4} \mathrm{~T}_{1 \mathrm{~g}} \rightarrow{ }^{4} \mathrm{~A}_{1 \mathrm{~g}}$ \\
& 491 & ${ }^{4} \mathrm{~T}_{1 \mathrm{~g}} \rightarrow{ }^{4} \mathrm{~T}_{2 \mathrm{~g}}$ \\
{$\left[\mathrm{Co}(\mathrm{Phen})_{2}\left(\mathrm{H}_{2} \mathrm{O}\right)_{2}\right] \mathrm{Cl}_{2}$} & 362 & $\mathrm{n} \rightarrow \pi^{*}(\mathrm{C}=\mathrm{N})$ \\
& 643 & ${ }^{4} \mathrm{~T}_{1 \mathrm{~g}}(\mathrm{~F}) \rightarrow{ }^{4} \mathrm{~T}_{1 \mathrm{~g}}(\mathrm{P})$ \\
& 662 & ${ }^{4} \mathrm{~T}_{1 \mathrm{~g}} \rightarrow{ }^{4} \mathrm{~A}_{2 \mathrm{~g}}$ \\
{$\left[\mathrm{Co}(\mathrm{Phen})_{2}(\mathrm{Cyt})\left(\mathrm{H}_{2} \mathrm{O}\right)\right] \mathrm{Cl}$} & 709 & ${ }^{4} \mathrm{~T}_{1 \mathrm{~g}} \rightarrow{ }^{4} \mathrm{~T}_{2 \mathrm{~g}}$ \\
& 412 & $\mathrm{n} \rightarrow \pi^{*}(\mathrm{C}=\mathrm{O})$ \\
& 647 & ${ }^{4} \mathrm{~T}_{1 \mathrm{~g}}(\mathrm{~F}) \rightarrow{ }^{4} \mathrm{~T}_{1 \mathrm{~g}}(\mathrm{P})$ \\
& 665 & ${ }^{4} \mathrm{~T}_{1 \mathrm{~g}} \rightarrow{ }^{4} \mathrm{~A}_{2 \mathrm{~g}}$ \\
\hline
\end{tabular}

\section{IR Spectrum of the Ligands and Co(II) Complexes}

The IR spectra of the complexes demonstrate that all the ligands are coordinated to the metal (Figure 2). The bands at $1506 \mathrm{~cm}^{-1}(\mathrm{~s}), 1585$ $\mathrm{cm}^{-1}$ characteristic for $\mathrm{vC}=\mathrm{C}$ and $1418 \mathrm{~cm}^{-1}(\mathrm{~s})$ characteristic for $v \mathrm{C}=\mathrm{N}$ stretching in the free 1,10-phenanthroline monohydrate appear shifted to $1525 \mathrm{~cm}^{-1}(\mathrm{w}), 1644(\mathrm{w})$ and $1384 \mathrm{~cm}^{-1}$ (s), respectively, in $\left[\mathrm{Co}(\mathrm{Phen})_{2}(\mathrm{Cyt})\left(\mathrm{H}_{2} \mathrm{O}\right)\right] \mathrm{Cl}$. They also appeared at $1522 \mathrm{~cm}^{-1}(\mathrm{w}), 1628 \mathrm{~cm}^{-1}(\mathrm{w})$, respectively, in $\left[\mathrm{Co}(\mathrm{Phen})_{2}\left(\mathrm{H}_{2} \mathrm{O}\right)_{2}\right] \mathrm{Cl}$. Similarly, the coordination of cytoside to the metal ion is evident from the appearance of strong sharp peaks at $1684 \mathrm{~cm}^{-1}$ characteristic for $\mathrm{vC}=\mathrm{O}$. The shift in the characteristic $v \mathrm{C}=\mathrm{O}$ of free cytosine from 1669 $\mathrm{cm}^{-1}$ to $1684 \mathrm{~cm}^{-1}$ indicates the increase in the $\mathrm{C}-\mathrm{O}$ bond multiplicity. Furthermore, $3465 \mathrm{~cm}^{-1}$ and $3352 \mathrm{~cm}^{-1}$ regions were assignable, respectively, to the asymmetric and symmetric stretching of terminal $\mathrm{NH}_{2}$ of cytoside mixed with $v_{\mathrm{OH}}$ of the coordinated water (Verma et al., 2012) (Figure 2). Because the two phenanthroline molecules already occupied the four coordination sites in a square planar geometry, cytoside is acting as a monodentate ligand coordinated to $\mathrm{Co}$ (II) via deprotonated ring nitrogen. The justification for this is that metal ions with oxidation state +2 at the right of $\mathrm{Mn}$ in the $3 d$ series of the periodic table are classified as acids with intermediate hardness. These ions prefer to bind to bases with similar hardness. The latter include $s p^{3}$ hybridized $\mathrm{N}$ containing molecules (Huheey et al., 1993). The side primary amine nitrogen cannot be used for binding. This is due to the fact that the electron pairs that could be used for coordinate covalent bonding are engaged in the resonance of the ring system. Moreover, the cytoside carbonyl oxygen is $s p^{2}$ hybridized hard base that does not form a stable bond with $\mathrm{Co}(\mathrm{II})$. 

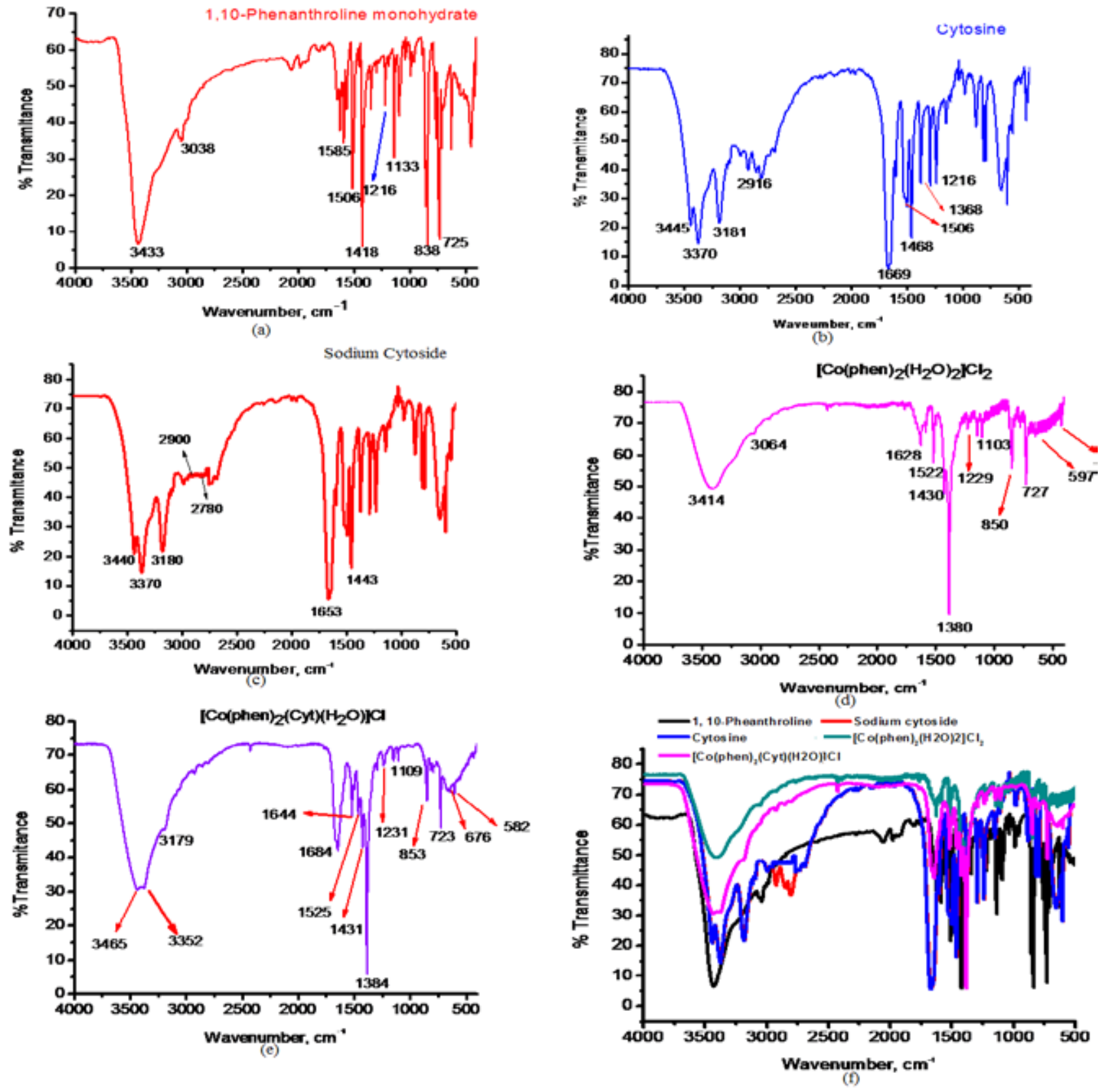

Figure 2: IR spectra of (a) 1,10-Phenanthroline monohydrate (b) Cytosine (c) Sodium cytoside (d) $\left[\mathrm{Co}(\mathrm{phen})_{2}\left(\mathrm{H}_{2} \mathrm{O}\right)_{2}\right] 2 \mathrm{Cl}$ (e) $\left[\mathrm{Co}(\mathrm{phen})_{2}(\mathrm{Cyt})\left(\mathrm{H}_{2} \mathrm{O}\right)\right] \mathrm{Cl}$ (f) IR spectra for all ligands and complexes together.

Antimicrobial activities of the salt, ligands and complexes

The biological activity investigations result shows that the complexes demonstrated biological activities against all the tested strains (Figure 3, Table 4). The observed increase in antibacterial activity can be explained on the basis of Overtone's concept (Dharmaraj et al., 2001) and Tweedy's chelation theory (Tweedy, 1964). The lipid membrane that surrounds the cell favors the passage of only lipid soluble materials due to which lipophilicity is an important factor which controls the antimicrobial activity. On coordination, the polarity of the metal ion will be reduced to a greater extent 
due to the overlap of the ligand orbitals and partial sharing of the positive charge of the metal ion with the donor groups. Further, it increases the delocalization of $\pi$-electrons over the whole chelate ring and hence enhances the liposolubility of the complexes. This increased liposolubility enhances the penetration of the complexes into the lipid membrane and interferes with the normal activities of the bacteria (Lakshmi et al., 2009).

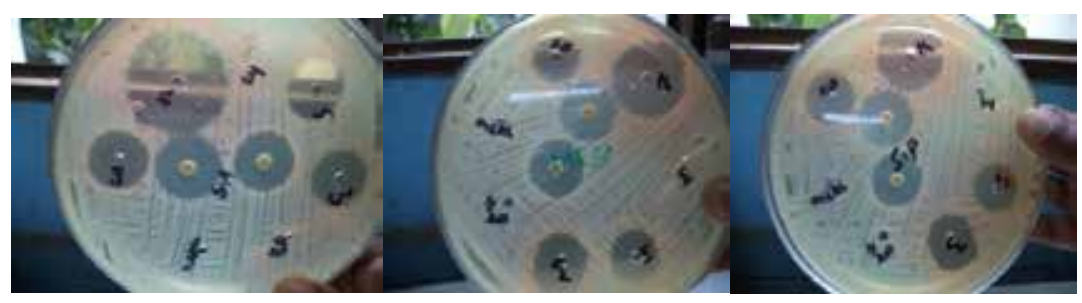

Gram-positive bacterial species

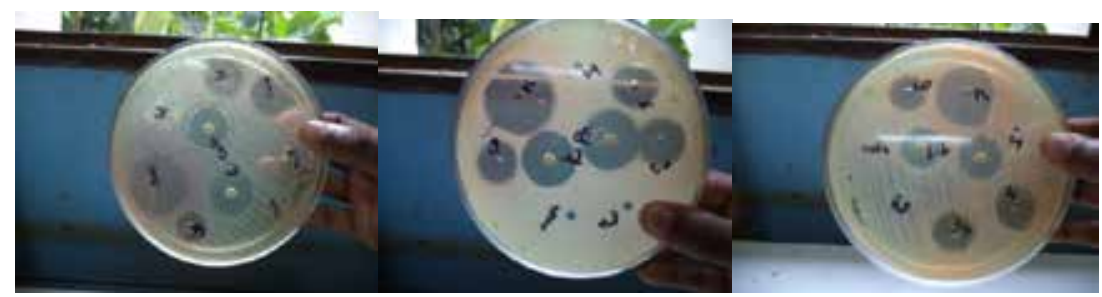

Gram-nogative bacterial species

S.A = Staphylococcus aureus, MRSA= Methicillin resistant Streptococcus aureus, S.p= Streptococcus pneumoniae, E.coli $=$ Escherichia coli and K.pn= Klebsella pneumoniae, $\mathrm{S} . \mathrm{b}=$ Shigella boydii and positive controls ; ciprofloxacin $(5 \mu \mathrm{g})$ and chloramphenicol $(30 \mu \mathrm{g})$.

Figure 3: Biological activity of cobalt salt, ligands, $\mathrm{Co}(\mathrm{II})$ complexes and reference antibiotics.

Table 4: Antibacterial activity of $\mathrm{CoCl}_{2} \cdot 6 \mathrm{H}_{2} \mathrm{O}$, ligands, metal complexes and reference antibiotic

\section{Antimicrobial activity ( mean IZ diameter $(\mathrm{mm}) \pm$ SD)}

\begin{tabular}{lllllll} 
Compounds & S. aureus & MRSA & S. pneumoniae & E. coli & K. pneumoniae & S. boydii \\
\hline$\left[\mathrm{Co}(\mathrm{Phen})_{2}(\mathrm{Cyt})\left(\mathrm{H}_{2} \mathrm{O}\right)\right] \mathrm{Cl}$ & $25.3 \pm 1.15$ & $28.3 \pm 0.57$ & $28.0 \pm 1.00$ & $32.3 \pm 0.57$ & $28.0 \pm 1.00$ & $23.3 \pm 0.57$ \\
{$\left[\mathrm{Co}(\mathrm{Phen})_{2}\left(\mathrm{H}_{2} \mathrm{O}\right)_{2}\right] \mathrm{Cl}_{2}$} & $23.3 \pm 0.57$ & $23.3 \pm 1.52$ & $25.6 \pm 1.15$ & $26.3 \pm 1.52$ & $26.3 \pm 0.57$ & $24.0 \pm 1.00$ \\
$\mathrm{CoCl}_{2} .6 \mathrm{H}_{2} \mathrm{O}$ & $23.0 \pm 1.00$ & $21.3 \pm 0.57$ & $22.6 \pm 1.50$ & $20.3 \pm 1.52$ & $22.6 \pm 1.15$ & $21.3 \pm 1$ \\
Cytosine & 0 & 0 & 0 & 0 & 0 & 0 \\
$1,10-$ Phenanthroline & $40.0 \pm 1.00$ & $34.6 \pm 1.15$ & $36.3 \pm 0.57$ & $34.0 \pm 1.00$ & $39.0 \pm 1.00$ & $21.3 \pm 1.00$ \\
Ciprofloxacin & $26.0 \pm 1.00$ & $25.3 \pm 1.15$ & $24.3 \pm 0.15$ & $26.3 \pm 1.50$ & $30.6 \pm 0.57$ & $23.3 \pm 1.00$ \\
Chloramphenicol & $28.6 \pm 0.57$ & $27.0 \pm 1.00$ & $28.3 \pm 0.57$ & $26.6 \pm 1.50$ & $33.6 \pm 0.57$ & $26.3 \pm 0.57$ \\
Methanol & 0 & 0 & 0 & 0 & 0 & 0 \\
Distilled water & 0 & 0 & 0 & 0 & 0 & 0 \\
\hline
\end{tabular}

$\mathrm{IZ}=$ inhibition zone. $\mathrm{SD}=$ Standard deviation, 


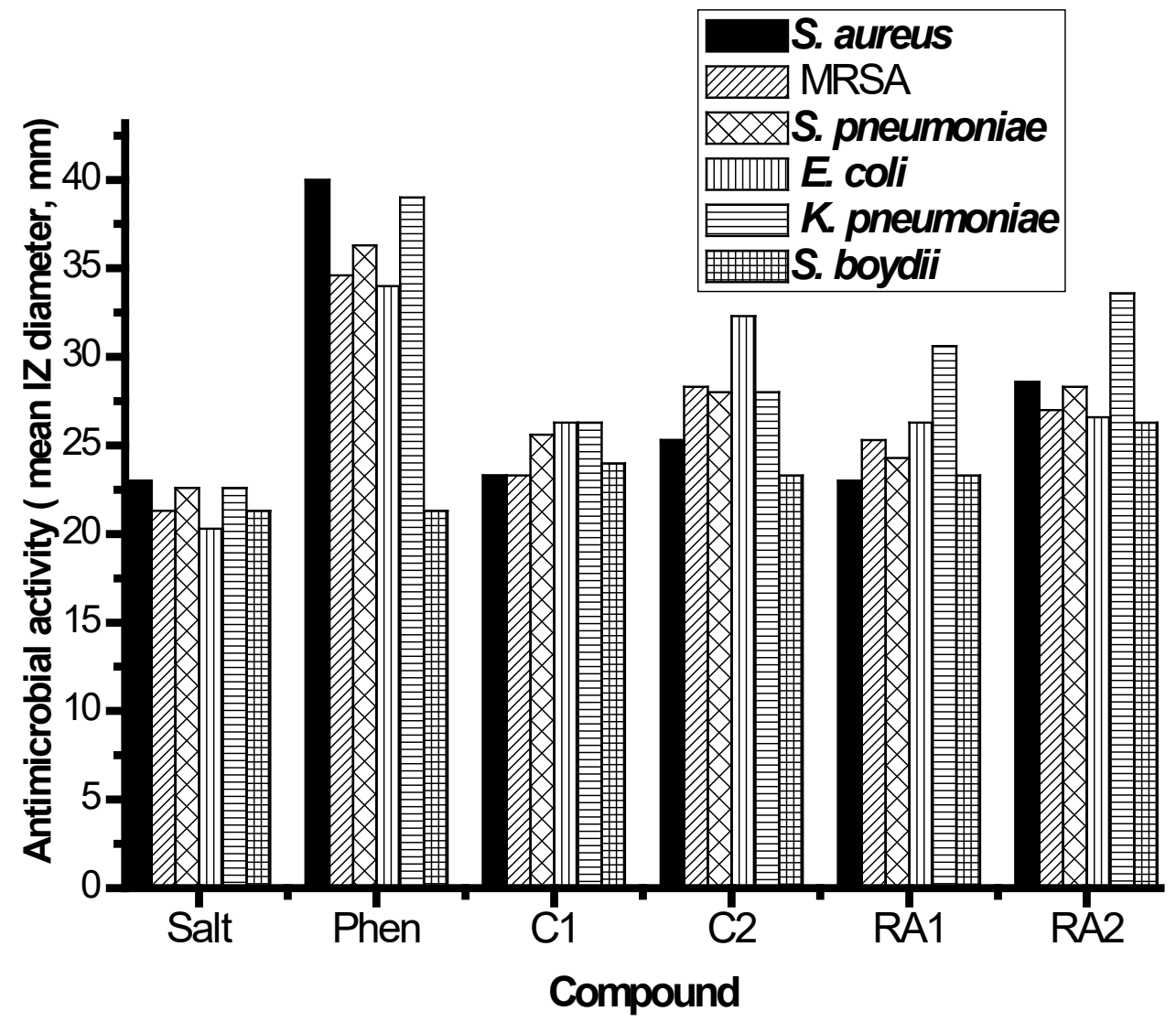

Salt $=\mathrm{CoCl}_{2} \cdot 6 \mathrm{H}_{2} \mathrm{O}, \mathrm{Cyt}=\mathrm{Cytosine}$, Phen $=1,10-$ Phenanthroline, $\mathrm{Cl}=\left[\mathrm{Co}(\mathrm{Phen})_{2}\left(\mathrm{H}_{2} \mathrm{O}\right)_{2}\right] \mathrm{Cl}_{2}, \mathrm{C} 2=\left[\mathrm{Co}(\mathrm{Phen})_{2}(\mathrm{Cyt})\left(\mathrm{H}_{2} \mathrm{O}\right)\right] \mathrm{Cl}$, RA1 $=$ Ciprofloxacin, RA2 $=$ Chloramphenicol

Figure 4: Comparative antibacterial activity of metal salt, ligands, complexes and reference antibiotic.

Table 5: MIC Assay of $\left[\mathrm{Co}(\mathrm{Phen})_{2}(\mathrm{Cyt})\left(\mathrm{H}_{2} \mathrm{O}\right)\right] \mathrm{Cl}$ against tested bacterial pathogens

\begin{tabular}{llllllll}
\hline \multicolumn{8}{c}{ Observation of growth for each concentrations $/ \mu \mathrm{L} / \mathrm{mL}$} \\
Bacterial strains & $\mathbf{1 0 0}$ & $\mathbf{2 0 0}$ & $\mathbf{3 0 0}$ & $\mathbf{4 0 0}$ & $\mathbf{6 0 0}$ & $\mathbf{8 0 0}$ & $\mathbf{1 0 0 0}$ \\
\hline S. aureus & + & + & + & - & - & - & - \\
MRSA & + & + & - & - & - & - & - \\
S. pneumoniae & + & - & - & - & - & - & - \\
E. coli & + & + & - & - & - & - & - \\
K. pneumoniae & + & - & - & - & - & - & - \\
S.boydii & + & + & + & - & - & - & - \\
\hline
\end{tabular}

Note: $+=$ Growth of bacteria, $-=$ No growth of bacteria.

The result showed that around $200 \mu \mathrm{L} / \mathrm{mL}$ of $\left[\mathrm{Co}(\mathrm{Phen})_{2}(\mathrm{Cyt})\left(\mathrm{H}_{2} \mathrm{O}\right)\right] \mathrm{Cl}$ is sufficient to inhibit $S$. pneumoniae and $K$. pneumoniae

MRSA and E. coli need around $300 \mu \mathrm{L} / \mathrm{mL}$. S. aureus and $S$. boydii require minimum of $400 \mu \mathrm{L} / \mathrm{mL}$. 
Determination of the Minimum Inhibitory

Concentrations (MIC) of $\left[\mathrm{Co}(\text { Phen })_{2}(\mathrm{Cyt})\right.$ $\left.\left(\mathrm{H}_{2} \mathrm{O}\right)\right] \mathrm{Cl}$

MIC is the lowest concentration that completely inhibited the growth of microorganisms for 24 hours. The percent activity indexes of the complexes about the reference antibiotics were investigated, and they demonstrated significant comparative activity (Table 6$).\left[\mathrm{Co}(\mathrm{Phen})_{2}(\mathrm{Cyt})\right.$
$\left.\left(\mathrm{H}_{2} \mathrm{O}\right)\right] \mathrm{Cl}$ demonstrated better activities than ciprofloxacin against MARSA, S. pneumoniae, and $E$. coli and equivalent activity against $S$. boydii. (Table 6). Similarly, it showed better activities than ciprofloxacin against MRSA and E. coli (Table 6). On the other hand, $\left[\mathrm{Co}(\mathrm{Phen})_{2}\left(\mathrm{H}_{2} \mathrm{O}\right)_{2}\right] \mathrm{Cl}_{2}$ showed better activities than chloramphenicol against $S$. pneumoniae and $S$. boydii and equivalent activity against $E$. coli.

Table 6: The \% Activity Index data of the complexes against the tested bacteria compared to ciprofloxacin and chloramphenicol

\begin{tabular}{|c|c|c|c|c|c|c|c|c|c|c|c|c|}
\hline \multirow[b]{2}{*}{ Compound } & \multicolumn{2}{|c|}{ S. aureus } & \multicolumn{2}{|c|}{ MRSA } & \multicolumn{2}{|c|}{ S. pneumoniae } & \multicolumn{2}{|c|}{ E. coli } & \multicolumn{2}{|c|}{ K. pneumoniae } & \multicolumn{2}{|c|}{ S. boydii } \\
\hline & Cip & Chlo & Cip & Chlo & Cip & Chlo & Cip & Chlo & Cip & Chlo & Cip & Chlo \\
\hline$\left[\mathrm{Co}(\text { Phen })_{2}\left(\mathrm{H}_{2} \mathrm{O}\right)_{2}\right] \mathrm{Cl}_{2}$ & -10.38 & -18.53 & -7.91 & -13.70 & 5.35 & -9.54 & 0 & -1.13 & -14.05 & -21.73 & 3.00 & -8.75 \\
\hline $\begin{array}{l}{\left[\mathrm{Co}(\mathrm{Phen})_{2}(\mathrm{Cyt})\right.} \\
\left.\left(\mathrm{H}_{2} \mathrm{O}\right)\right] \mathrm{Cl}\end{array}$ & -2.70 & -11.54 & 11.86 & 4.81 & 15.23 & -1.06 & 22.81 & 21.43 & -8.50 & -16.67 & 0 & -11.41 \\
\hline
\end{tabular}

MRSA $=$ Methicillin resistant $S$. aureus, Cip $=$ ciprofloxacin, Chlo $=$ chloramphenicol

\section{CONCLUSION}

The synthesis brought about $\mathrm{Co}(\mathrm{II})$ and the ligands in a rigid configuration. This resulted in convenient electronic environment by the delocalization of $\pi$-electrons over the whole cationic unit. The latter phenomena reduced the polarity of the complexes which increased the liposolubility. Consequently, the penetration of the complexes into the cell wall and lipid membrane is enhanced which inhibits the growth of the tested gram-positive and gram-negative bacteria. The latter phenomenon demonstrates the wide-range activities of the complexes.

\section{ACKNOWLEDGEMENTS}

We thank Bahir Dar University for the financial support.

\section{REFERENCES}

Ailhaud, G., Grimaldi, P and Negrel, R. (1992). Cellular and molecular aspects of adipose tissue development. Cellular and molecular aspects of adipose tissue development Annual Review of Nutrition 12:207-33. 
Ardiyanti, A., Oki, Y., Suda , Y., Suzuki, K., Chikuni, K., Obara, Y and Katoh, K. (2009). Effects of GH gene polymorphism and sex on carcass traits and fatty acid compositions in Japanese Black cattle. Animal Science Journal 80: 62-69.

Barendse, W., Harrison ,B.E., Hawken, R.J., Ferguson, D.M., Thompson, J. M., Thomas, $\mathrm{M}$ and Bunch, R..J. (2007). Epistasis between Calpain 1 and its inhibitor Calpastatin within breeds of cattle. Genetics 176:2601-2610.

Bartha, T., Sayed-Ahmeda, A and Rudas, P. (2005) Expression of leptin and its receptors in various tissues of ruminants. Domestic Animal Endocrinology 29:193-202.

Bastos, E., Alfredo, C., Azevedo, J and Pinto, H.G. (2001). Single strand conformation polymorphism (SSCP) detection in six genes in Portuguese indigenous sheep breed "Churrada Terra Quente". Biotechnology Agronomy and Social Environments 5 (1): 7-15.

Bionaz, M and Loor, J. J. (2008). ACSL1, AGPAT6, FABP3, LPIN1, and SLC27A6are the most abundant isoform in bovine mammary tissue and their expression is affected by stage of lactation. Journal of Nutrition 138: 10191024.

Biswas, T.K., Bhattacharya, T.K., Narayan, A.D., Badola, S., Kumar, P and Sharma, A. (2003). Growth hormone gene polymorphism and its effect on birth weight in cattle and buffalo. Asian Australian Journal of Animal Sciences 16: 494-497.

Blott, S., Kim, J.J., Moisio, S., Schmidt-Küntzel, A., Cornet, A., Berzi, P., Cambisano, N., Ford, C., Grisart, B., Johnson, D., Karim, L., Simon, P., Snell, R., Spelman, R., Wong, J., Vilkki, J., Georges, M., Farnir, F and Coppieters, W. (2003). Molecular dissection of a quantitative trait locus: a phenylalanine- to-tyrosine substitution in the trans membrane domain of the bovine growth hormone receptor is associated with a major effect on milk yield and composition. Genetics 163: 253-266.

Brettes, J.P and Mathelin, C. (2008). Effete dual des androgens surla glande mammaire. Bulletin $d u$ Cancer (Paris) 95: 495-502.

Brymp P, Kaminski S and Wojcik E. (2005). Nucleotide sequence polymorphism within exon 4 of the bovine prolactin gene and its associations with milk performance traits. Animal Genetics 45(2): 179-85.

Buchanan,F.C., Fitzsimmons, C.J., vankessel, A.G., Thue, T.D., Sim,D.C.W and Schmitz S.M. (2002). Association of a missense mutation in the bovine leptin gene with carcass fat content and leptin MiRNA levels. Genetic Selection Evolution 34 (1): 105-116.

Casas, E.S.N., White, T.L., Wheeler, S.D. Shackelford, M., Koohmaraie, D.G., Riley, C.C., Chase, J.R., Johnson, D.D and Smith, T.P.L. (2006). Effects of calpastatin and $\mu$-calpain markers in beef cattle on tenderness traits. Journal of Animal Sciences 84: 520-525.

Chilliard, Y., Delavaud, C and Bonnet, M. (2005). Leptin expression in ruminants: Nutritional and physiological regulations in relation with energy metabolism. Domestic Animal Endocrinology 29: 3-22.

Chmurzynska, A. (2006). The multigene family of fatty acid-binding proteins (FABPs): function, structure and polymorphism. Journal of Applied Genetics 47: 39-48.

Clark, R.B., Bishop-Bailey, D., Estrada-Hernandez T., Hla, T., Puddington, L and Padula, S.J. (2000). The nuclear receptor PPAR and immuno regulation: PPAR mediates inhibition of helper $\mathrm{T}$ cell responses. Journal of Immunology 164: 1364-1371. 
Clempson, A. M., Pollott, G. E., Brickell, J. S., Bourne, N. E., Munce N and Wathes, D.C. (2011). Evidence that leptin genotype is associated with fertility, growth, and milk production in Holstein cows. Journal of Dairy Sciences 94: 3618-3628.

Cunningham, M.J.,Clifton, D.K and Steuner, R.A. (1999). Leptin actions on the reproductive axis: Perspective and mechanisms. Biology and Reproduction 60: 216-222.

Daetwyler, H.D, Schenkel, F.S., Sargolzaei, M and Robinson, J.A. (2008). A genome scan to detect quantitative trait loci for economically important traits in Holstein cattle using two methods and a dense single nucleotide polymorphism map. Journal of Dairy Sciences 91:3225-3236.

Deshaies, R.J., Koch, B.D., Werner-Washburne, M., Craig, E. A and Schekman. R. (1988). A subfamily of stress proteins facilitates translocation of secretory and mitochondrial precursor polypeptides. Nature 332: 800-805.

Dikmen S and Hansen P.J. (2009). Is the temperature-humidity index the best indicator of heat stress in lactating dairy cows in a subtropical environment? Journal of Dairy Science 92:109-116.

Erhardt G, Godovac-Zimmermann J, Juszczak J, Prinzen- berg EM, Krick-Saleck H and Panicke, L. (1997). Milk protein polymorphism in Polish and German Red Cattle and the characterization of a new genetic f-lactoglobulin variant. Proceedings of the 48th EAAP Meeting, 25th - 28th August. pp 1-7.Vienna, Austria,

Fahlman, A., Storey, J.M and Storey, K.B. (2000). Gene up-regulation in heart during mammalian hibernation. Cryobiology 40(4):332-342.

Farese, J.R., Cases, S and Smith, S.J. (2000). Triglyceride synthesis: insights from the cloning of diacylglycerol acyltransferase. Current Opinion in Lipidology 11:229-234.

Farias, S. T and Bonato, M. C. (2003). Preferred amino acids and thermostability. Genetic and Molecular Resources 2:383-393.

Farrell, H.M, Jimenez-Flores, R., Bleck, G.T., Brown, E.M., Butler, J.E., Creamer, L.K., Hicks, C.L., Hollar, C.M., Ng-Kwai-Hang, K.F and Swaisgood, H.E. (2004). Nomenclature of the proteins of cows' milk sixth revision. Journal of Dairy Sciences 87(6):1641-1674.

Galtier, N and Lobry, J. R. (1997). Relationships between genomic $\mathrm{G}+\mathrm{C}$ content, RNA secondary structures, and optimal growth temperature in prokaryotes. Journal of Molecular Evolution 44: 632-636.

Gaughan, J.B and Cawsell-Smith, A. J. (2015). Impact of climate change on livestock production and reproduction. In: Climate change Impact on livestock: adaptation and mitigation, pp 51-60 ,New Delhi, India.

Gaughan, J. B., Holt, S. M., Hahn, G. L., Mader T. L and Ei- genberg. R. A.. (2000). Respiration rate - is it a good measure of heat stress in cattle? Asian- Australian Journal of Animal Sciences 13(Supplement C): 329-332.

Grisart, B., Coppieters, W., Farnir, F., Karim, L., Ford, C., Berzi, P., Cambisano, N., Mni, M., Reid, S., and Simon, P. (2002). Positional candidate cloning of a QTL in dairy cattle: identification of a missense mutation in the bovine DGAT1 gene with major effect on milk yield and composition. Genome Restoration 12: 222-231.

Hadecka E, Čitek J, Panicke L, ̌̌ehout V and Hanusova L. (2008). The relation of GH1,GHR and DGAT1 polymorphisms with estimated breeding values for milk production traits of German Holstein sires. Czech Journal of Animal Sciences 53: 238-245. 
Hale, C.S., Herring, W.O., Shibuya, H., Lucy, M.C., Lubahn, D.B and Keisler, D.H. (2000). Decreased growth in Angus steers with a short TG-microsatellite allele in the $\mathrm{P} 1$ promoter of the growth hormone receptor gene. Journal of Animal Sciences 78, 2099-2104.

Hall, S.J.G. (2004). Livestock Biodiversity. Genetic Resources for the Farming of the Future. Blackwell, Oxford. England.

Hamza, A. E., Yang , Z. P., Wang , X. L., Chen, R. J., Wu, H. T and Ibrahim, A. I. (2010). The Impact of Kappa Casein Gene Polymorphism on Milk Components and Other Productive Performance Traits of Chinese Holstein Cattle. Pakistan Veterinary Journal 31(2): 153-156.

Hayes B. J., Bowman P. B., Chamberlain A. C., Verbyla K and Goddard M. E. (2009) Accuracy of genomic breeding values in multi-breed dairy cattle Populations. Genetics Selection Evolution 24: 41- 51.

Hoffmann, I. (2010). Climate change and the characterization, breeding and conservation of animal genetic resources. Animal Genetics 41(1): 32-46.

Jendrzejczyk, M., Grzesiak, W., Szatkowska, I., Dybus, A., Muszynska, M and Zaborski, D. (2011). Association between polymorphisms of CYP19, CYP21 and ER1genes and milk production traits in Black-and-White cattle. Turkey Journal of Veterinary and Animal Sciences 35: 41-49.

Jiang, Z., Michal, J.J., Tobey, D.J., Daniels,T.F., Rule, D.C and Mac Neil, M.D. (2008). Significant association of Stearoyl-CoA desaturase (SCD1) gene with fat deposition and composition in skeletal muscle. International Journal of Biological Sciences 4:345-351.

Kadokawa, H., Blanche D and Martin, G. B. (2006). Plasma leptin concentrations correlate with luteinizing hormone secretion in early postpartum Holstein cows. Journal of Dairy Sciences 89: 3020-3027.

Kaupe, B., Brandt, H., Prinzenberg, E.M and Erhardt, G. (2007). Joint analysis of the influence of CYP11B1 and DGAT1 genetic variation on milk production, somatic cell score, conformation, reproduction, and productive lifespan in German Holstein cattle. Journal of Animal Science 85:11-21.

Kefyalew Alemayehu and Tegegn Fantahun (2012). The Effect of Climate Change on Ruminant Livestock Population Dynamics in Ethiopia. Livestock Research for Rural Development $\mathbf{2 4}$ (10).1-10.

Kefyalew Alemayehu and Damitie Kebede (2015). Molecular mechanis ms and the roles of protein in underlying animal adaptation. Global Journal of Animal Science, Livestock Production and Animal Breeding 3 (6): 217226.

Kefyalew Alemayehu and Addisu Getu (2016). Impacts of climate variability on livestock population dynamics and beed distribution patterns in selected districts of Western Amhara, Ethiopia. Cambridge Journal of Animal Genetic Resources 59: 113-121.

Khatib, H., Maltecca, C., Monson, R.L., Schutzkus, V and Rutledge, J.J. (2009). Monoallelic maternal expression of STAT5A affects embryonic survival in cattle. BMC Genetics 10:13-22.

Kendall, N.R., Gutierrez, C.G., Scaramuzzi, R.J., Baird, D.T., Webb, R and Campbell, B.K. (2004). Directin vivo effects of leptin on ovarian steroid genesis in sheep. Reproduction 128:757-765.

Koohmaraie, M. (1994) .Muscle proteinases and meat aging. Meat Science 36: 93-104. 
Kovács, K., Völgyi-Csík, J., Zsolnai, A., Györkös, I and Fésüs, L. (2006). Associations between the AluI polymorphism of growth hormone gene and production and reproduction traits in a Hungarian Holstein-Friesian bull dam population. Archive Tierz 49: 236-249.

Krum, S.A., Womack, J.E and Lane, T.F. (2003). Bovine BRCA1 shows classic responses to geno toxic stress but low in vitro transcriptional activation activity. Oncogene 22: 6032-6044.

Kubiak, E.J., Wyszynska-Koko, J., Wicinska K and Rosochacki, S. (2008). A novel polymorphisms in introns 12 of the bovine calpastatin gene. Molecular Biology and Reproduction 35: 29-35.

Liu, W.J., Fang, G.X., Fang, Y., Tian, K.C., Huang, X.X., Yao, X.K., Wang, M., Yu, H., Huang, Y.Z., Xin, J.J., Xin, Y.P., Yu, S.G and Chen, H., (2010). The polymorphism of a mutation of IGF1 gene on two goat breed of China. Journal of Animal Sciences and Veterinary Advancements 9: 790-794.

Li A, Omura N, Hong SM, Vincent A, Walter K and Griffith M (2010). Pancreatic cancers epigenetically silence SIP1 and hypomethylate and overexpress miR-200a/200b in association with elevated circulating miR-200a and miR$200 b$ levels. Cancer Research 70: 5226-5237.

Lord ,G.M., Materese, G., Howard, J. K., Baker, R.J., Bloom, S.R and Lechler, R.I. (1998). Leptin modulates the T-cell immune response and reverses starvation -induced immuno suppression. Nature 394:897-901.

Maak, S., Neumann, K and Swalve, H. H. (2006). Identification and analysis of putative regulatory sequences for theMYF5/MYF6 locus in different vertebrate species. Genetics 379: 141-147.
Marchitelli, C. (2013). Milk fatty acid variability: effect of some candidate genes involved in lipid synthesis. Journal of Dairy Resources 80:165-173.

Martin, P., Szymanowska, M., Zwierzchowski, L and Leroux, C. (2002). The impact of genetic polymorphisms on the protein composition of ruminant milk. Reproduction Nutrition and development 42:433-459.

Michael, D.D., Alvarex, I.M., Ocón, O.M., Powell, A.M., Talbot, N.C., Johnson, S.E and Ealy, A.D. (2006). Fibroblast growth factor-2 is expressed by the bovine uterus and stimulates interferontau production in bovine trophectoderm. Endocrinology 147: 3571-3579.

Michal, J. J., Zhang, Z.W., Gaskins, C.T and Jiang, Z. (2006). The bovine fatty acid binding protein 4 gene is significant associated with marbling and subcutaneous fat depth in wagyu $\mathrm{x}$ limousine F2 crosses animal. Genetics 37:400-402.

Milanesi, E., Nicoloso, L and Crepaldi, P. (2007). Stearoyl CoA desaturase (SCD) gene polymorphisms in Italian cattle breeds . Journal of Animal Breeding and Genetics 125:63-67.

Miyataki, M and Ntambi, J.M. (2003) Role of Stearoyl -coenzyme a desaturase in lipid metabolism. Prostaglandins Leukot essent Fatty Acid 68:113-121.

Mullen, M.P., Lynch, C.O., Waters, S.M., Howard, D.J., Boyle, P.O., Kenny, D.A., Buckley, F., Horan, B and Diskin, M.G. (2011). Single nucleotide polymorphism in the growth hormone and insulin-like growth factor-I genes are associated with milk production, body condition score and fertility traits in dairy cows. Genetics and Molecular Resources 10: 1819-1830. 
Murdoch G.K, Dixon, W.T, Okine, E.K and Christopherson R.J. (2005). Bovine tissue mRNA abundance related to acute cold exposure and acute feeding restriction. Canadian Journal of Animal Sciences 85:157164.

Nafikov, R. A. (2013). Associations of polymorphisms in solute carrier family 27, isoform A6 (SLC27A6) and fatty acidbinding protein-3 and fatty acid-binding protein-4 (FABP3and FABP4) with fatty acid composition of bovine milk. Journal of Dairy Sciences 96: 6007-6021.

Nakashima, H, Fukuchi, S and Nishikawa, K (2003). Compositional changes in RNA, DNA and proteins for bacterial adaptation to higher and lower temperatures. Journal of Biochemistry (Tokyo) 133:507-513.

Näslund, J., Fikse, W.F., Pielberg, G.R and Lundén, A. (2008). Frequency and effect of the bovine acyl-CoA: diacylglycerol acyltransferase 1 (DGAT1) K232A polymorphism in Swedish dairy cattle. Journal of Dairy Science 91: 2127-2134.

Noguera, J.L., Varona L, Go'mez-Raya L and Sanchez, A. (2003). Estrogen receptor polymorphism in Landrace pigs and its association with litter size performance. Livestock Production Sciences 82:53-59.

Nonaka, S., Hashizume ,T and Kasuya, E. (2006). Effects of intra cerebro ventricular injections of leptin on the release of luteinizing hormone and growth hormone in castrated calves. Animal Sciences Journal 77: 196-200.

Ogorevc, J., Kunej, T., Razpet, A and Dovc, P. (2009). Database of cattle candidate genes and genetic markers for milk production and mastitis. Animal Genetics 40:832-851 .
Oikonomu, G., Angelopoulou, K., Arsenos, G., Zygoyiannis D and Banos, G. (2008). The effects of polymorphisms in the DGAT1, leptin and growth hormone receptor gene loci on body energy, blood metabolic and reproductive traits of Holstein cows. Animal Genetics 40: $10-17$.

Oprządek, J., Flisikowski, K., Zwierzchowski, L., Juszczuk-Kubiak, E., Rosochacki, S and Dymnicki, E. (2005). Associations between polymorphism of some candidate genes and growth rates, feed intake and utilization, slaughter indicators and meet quality in cattle. Archive Tierz 48: 81-87.

Pannier, L., Mullen, A.M and Hamill, R.M. (2010). Association analysis of single nucleotide polymorphisms in DGAT1, TG and FABP4 genes and intramuscular fat in crossbred Bos taurus cattle. Meat Science 85:515-518.

Pareek, C.S., Zieba, M., Michno, J., Czainik, U and Zwierzchowski, L. (2008). Study of SNP $\mathrm{C}:$ Tpolymorphism within the candidate genes for dairy and beef traits in a panel of selected cattle breeds. Journal of Agrobiology 25: 121124.

Paula-Lopes, (2003). Genetic divergence in cellular resistance to heat shock in cattle: differences between breeds developed in temperate versus hot climates in responses of preimplantation embryos, reproductive tract tissues and lymphocytes to increased culture temperatures. Reproduction 125: 285-294 .

Paz, A., Mester, D., Baca, I., Nevo, E and Korol, A. (2004). Adaptive role of increased frequency of polypurine tracts in mRNA sequences of thermophilic prokaryotes. Proceedings, National Academic Sciences, USA 101:29512956. 
Pfister-Genskow, M., H., Eggen Hayes, A and Bishop. M. D. (1997). The leptin receptor (LEPR) gene maps to bovine chromosome 3q33. Mamamalian Genome 8: 227.

Rahbar, R., Rahimi, G., Ansari Pirsaraei, Z and Gholizadeh, M. (2010). Identification of polymorphism in the promoter region of growth hormone receptor (GHR) gene and its association with milk-related traits in Holstein cows. African Journal of Biotechnology 9 (33): 5460-5.

Raynaud, P., Jayat-Vignoles, C., Laforêt, M. P., Levéziel, H and Amarger V. (2005). Four promoters direct expression of the calpastatin gene. Archive Biochemistry and Biophysics 437(1):69-77.

Russell, A.P and Holleman, D. S. (1974). The thermal denaturation of DNA: average length and composition of denatured areas. Nucleic Acid Research 1:959-978.

Schenkel, F. S., Miller, S. P., Ye, X., Moore, S. S and Nkurmah, J.D. (2005). Association of single nucleotide polymorphism in the leptin gene with carcass and meat duality of beef cattle trait. Journal of Animal Sciences 83: 2009-2020.

Schenkel,F.S., Miller, S.P., Moore, S.S. Li, C and Fu A.(2006). Association of a single nucleotide in the leptin and leptin receptor genes with different fat depos in beef cattle. In: Proceedings of the $8^{\text {th }}$ world congress on genetics applied to livestock production pp:1-4, Belo horizontal, Brazil.

Schennink, A., Bovenhuis, H., Léon- Kloosterziel, K. M.,Van Arendonk, J. A and Visker, M. H. (2009). Effect of poly-morphisms in the FASN, OLR1, PPARGC1A, PRL and STAT5A genes on bovine milk-fat composition. Animal Genetics 40: 909-916.
Schennink, A., Stoop, W.M. Visker, M.H.P., Heck, J.M.L and Bovenhuis, H. (2007). DGAT1 underlies large genetic variation in milk fat composition of dairy cows. Animal Genetics 38: 467-473.

Silva, A.M., Rios, A.F.L., Ramos, E.S., Lôbo, R.B., Oliveira, H.N and Freitas, M.A.R. (2011). Association between IGF2and CYP21gene polymorphisms and characteristics of economic interest in Nellore cattle. Genetic and Molecular Resources 10: 2140-2147.

Singer, G.A.C and Hickey, D.A. (2003). Thermophilic prokaryotes have characteristic patterns of codon usage, amino acid composition and nucleotide content. Genetics 317:39-47.

Singh, U., Deb, R., Alyethodi, R.R., Alex, R., Kumar, S., Chakraborty, S., Dhama, K and Sharma, A., (2014). Molecular markers and their applications in cattle genetic research: A review. Biomarkers and Genomic Medicine 6: 49-58.

Soria, L. A., Corva, P. M., Branda Sica, A., Villarreal, E. L., Melucci, L. M., Mezzadra, C. A., Papaleo Mazzucco, J., Fernández Macedo, G., Silvestro, C., Schor, A and Miquel, M. C. (2009). Association of a novel polymorphism in the bovine PPARGC1A gene with growth, slaughter and meat quality traits in Brangus steers. Molecular Cell Probes 23: 304-308.

Steinfeld, H., Gerber, P., Wassenaar, T., Castel, V., Rosales, M and de Haan, C. (2006). Livestock's Long Shadow: Environmental Issues and Options. FAO, Rome.

St-Pierre, N. R, Cobanov, B and Schnitkey, G. (2003). Economic losses from heat stress by US livestock industries. Journal of Dairy Science 86: 52-77. 
Szatkowska, I., Grzesiak, W., Jedrzejczak, M., Dybus, A., Zaborski, D and Jankowiak, D. (2011). An analysis of CYP19, CYP21and Ergeno types in Polish Holstein-Friesian cows with regard to the selected reproductive traits. Acta Veterinary,Brno 80: 65-71.

Tantia, M.S., Vijh, R.K., Mishra, B.P., Mishra, B., Kumar, S.T.B and Sodhi, M. (2006). DGAT1 and ABCG2 polymorphism in Indian cattle (Bos indicus) and buffalo (Bubalus bubalis) breeds. Veterinary Research 2:32-36.

Thidar, M, H., Yoshida, H., Ito, T., He, M., Inoue, $\mathrm{H}$ and Kuwayama, H. (2008). Combined administration of ghrelin and GHRH synergistically stimulates $\mathrm{GH}$ release in Holstein pre weaning calves. Domestic Animals Endocrinology 34: 118-123.

Thornton, P., Herrero, M., Freeman, A., Mwai, O., Rege, E., Jones, P and McDermott, J. (2007). Vulnerability, Climate change and Livestock - Research Opportunities and Challenges for Poverty Alleviation. International Livestock Research Institute (ILRI), Kenya.

Thornton, P.K., van de Steeg ,J., Notenbaert, A and Herrero, M. (2009). The impacts of climate change on livestock and livestock systems in developing countries: A review of what we know and what we need to know. Agricultural Systems 101: 113-127.

Verner, J., Humpolicek, P and Knoll, A. (2007). Impact of MYOD family genes on pork traits in Large White and Landrace pigs. Journal of Animal Genetics and Breeding 124: 81-85.

Wang, H.C., Singer, G.A.C and Hickey, D.A. (2004). Mutational bias affects protein evolution in flowering plants. Molecular Biology and Evolution 21:90-96.

Wathes, D.C., Fenwick, M., Cheng, Z., Bourne, N., Llewellyn, S., Morris, D.G., Kenny, D., Murphy, J and Fitzpatrick, R. (2007). Influence of negative energy balance on cyclicity and fertility in the high producing dairy cow. Theriogenology 68: 232-41.

Weikard, R,, Kuhn, C., Goldammer, T., Freyer, $\mathrm{G}$ and Schwerin, M. (2005). The bovine ppargc la gene: Molecular characterization and association of an snp with variation of milk fat synthesis. Physiol. Genomics 21:1-13.

Wibowo, T.A., Gaskins, C.T., Newberry, R.C., Thorgaard, G.H., Michal, J.J and Jiang, Z. (2008). Genome assembly anchored QTL map of bovine chromosome 14. International Journal of Biological Sciences 4: 406-414.

Yazawa, T., Inaoka, Y., Okada, R., Mizutani, T., Yamazaki, Y., Usami, Y., Kuribayashi, M., Orisaka, M., Umezawa, A and Miyamoto, K. (2010). PPAR-gamma coactivator1alpha regulates progesterone production in ovarian granulosa cells with SF-1 and LRH1. Molecular Endocrinology 24:485-496.

Zhang, H.M., Brown, D.R., Denise, S.K and Ax, R.L. (1993). Rapid communication: polymerase chain reaction-restriction fragment length polymorphism analysis of the bovine somatotropin gene. Journal of Animal Sciences 71: 2276-2279.

Zhu, L., Ke, Y., Shao, D., Cui, Y., Qiao, A., Liu, X., Fang, F and Chang, Y. (2010). Pparã coactivator-1á co-activates steroidogenic factor 1 to stimulate the synthesis of luteinizing hormone and aldosterone. Biochemistry Journal 432: 473-483.

Zumbach, B., Misztal, I., Tsuruta, S., Sanchez, J.P, Azain, M., Herring W, Holl J, Long T and Culbertson, M. (2008). Genetic components of heat stress in finishing pigs: Development of a heat load function. Journal of Animal Science 86: $2082-2088$. 